\title{
Tumor Promoter
}

National Cancer Institute

\section{Source}

National Cancer Institute. Tumor Promoter. NCI Thesaurus. Code C914.

An agent that acts at stage 2 of carcinog enesis, following the initiation of increased cell proliferation. It is a necessary step in overt tumor formation. 